\title{
KELAYAKAN FINANSIAL USAHA PERIKANAN TANGKAP DI SELAT BALI
}

\author{
(FINANCIAL FEASIBILITY OF CAPTURE FISHERIES IN THE BALI STRAIT)
}

\author{
Syafril Fauzi ${ }^{1,2}$, Budhi Hascaryo Iskandar ${ }^{3}$, Bambang Murdiyanto ${ }^{3}$, dan Eko Sri Wiyono ${ }^{3}$ \\ Ditjen Pengolahan dan Pemasaran Hasil Perikanan (P2HP) \\ Kementerian Kelautan dan Perikanan
}

\begin{abstract}
Fishing effort become the dominant (about 80\%) of the fishing economy and society in the Bali Strait. This situation quiet long when fishing effort is not well managed and there is no balance in financial terms. This study will assess the condition of investment, operational, and financial feasibility of the fishing effort. The method used consisted of investment analysis, NPV, IRR, ROI and BCR. The analysis showed that investment needs purse seine OBS, purse seine TBS, gill nets and payang is \$ 287,750.000, Rp 476.25 million, $\mathrm{Rp} 313,250,000$ and $\mathrm{R} p$ 261,150,000. The annual operational needs OBS purse seine, purse seine TBS, gill nets and successive payang is \$261,965,000, USD 408.87 million, Rp 234,550,000 and Rp 188,717,500. While the annual revenue purse seine OBS, purse seine TBS, gill nets and payang is $\mathrm{R} p$ 992,928,000, Rp 1,998,132,000, Rp 673,292,000 and Rp 636,290,000. These four fishing gear are 'very feasible' developed in Bali strait, because it has the value of NPV, IRR, ROI, and B/C ratio is better than required. Purse seine OBS have $\mathrm{R} p$ 1,755,080,046.41 NPV, IRR of approximately 102.55\%, ROI around 21.22, and R/C ratio of about 1.40. Purse seine TBS has NPV around Rp 4,070,067,018.54, IRR around 140.15\%, ROI around 25.80, and R/C ratio about 1.50. Gill net has a NPV about Rp 918,548,267.25, IRR about 53.08\%, ROI around 13.66, and R/C ratio about 1.27, and payang bave NPV around Rp 982,670,737.88, IRR of approximately 66,25\%, ROI around 14.98, and R/C ratio about 1.34 .
\end{abstract}

Keywords: financial, investment, fishing capture

\begin{abstract}
ABSTRAK
Usaha perikanan tangkap menjadi tumpuan dominan (sekitar $80 \%$ ) dari ekonomi nelayan dan masyarakat di kawasan Selat Bali. Namun hal ini tidak akan bertahan lama bila usaha perikanan tangkap tersebut tidak dikelola dengan baik dan tidak ada perimbangan dalam hal finansial. Penelitian ini akan mengkaji kondisi investasi, operasional, dan kelayakan finansial dari usaha perikanan tangkap tersebut terutama. Metode yang digunakan terdiri analisis investasi, NPV, IRR, ROI dan BCR. Hasil analisis menunjukkan kebutuhan investasi purse seine OBS, purse seine TBS, gill net dan payang berturut-turut adalah Rp 287,750.000, Rp 476.250.000, Rp 313.250.000, dan Rp 261.150.000. Kebutuhan operasional tahunan purse seine OBS, purse seine TBS, gill net dan payang berturut-turut adalah Rp 261.965.000, Rp 408.870.000, Rp 234.550.000, dan Rp 188.717.500. Sedangkan penerimaan tahunan purse seine OBS, purse seine TBS, gill net dan payang berturut-turut adalahRp 992.928.000, Rp 1.998.132.000, Rp 673.292.000, dan Rp 636.290.000. Keempat usaha perikanan tersebut termasuk 'sangat layak' dikembangkan di kawasan Selat Bali, karena mempunyai nilai NPV, IRR, ROI, maupun B/C Ratio yang lebih baik dari yang dipersyaratkan. Purse seine OBS mempunyai NPV sekitar Rp 1.755.080.046,41, IRR sekitar 102,55 \%, ROI sekitar 21,22, dan R/C ratio sekitar 1,40. Purse seine TBS mempunyai NPV sekitar Rp 4.070.067.018,54, IRR sekitar 140,15\%, ROI sekitar 25,80, dan R/C ratio sekitar 1,50. Gill net mempunyai NPV sekitar Rp 918.548.267,25, IRR sekitar $53,08 \%$, ROI sekitar 13,66, dan $\mathrm{R} / \mathrm{C}$ ratio sekitar 1,27, dan payang mempunyai NPV sekitar Rp 982.670.737,88, IRR sekitar 66,25 \%, ROI sekitar 14,98, dan R/C ratio sekitar 1,34.
\end{abstract}

Kata kunci : finansial, investasi, usaha perikanan tangkap

\section{PENDAHULUAN}

Produksi menjanjikan di kawasan Selat Bali terutama dari jenis ikan lemuru. Menurut DKP (2008) dan Tinungki (2005), produksi ikan lemuru di Selat Bali terbagi dalam tiga daerah yaitu
$49 \%$ dari total produksi, dan Muncar 13.099,65 ton per tahun atau $47 \%$ dari total produksi.

Kondisi ini menyebabkan banyak usaha perikanan tangkap berkembang. Menurut Dinas Kelautan dan Perikanan Propinsi Jawa Timur (2009), purse seine merupakan usaha perikanan tangkap

\footnotetext{
${ }^{1}$ Corresponding author

${ }^{2}$ Peneliti P2HP-Kementerian Kelautan dan Perikanan- RI

${ }^{3}$ Staf pengajar Departemen Pemanfaatan Sumberdaya Perikanan, FPIK-IPB
} 
kabupaten Buleleng 1.208,17 ton per tahun atau $4 \%$ dari total produksi ikan lemuru di Selat Bali, kabupaten Jembrana 13.574,91 ton per tahun atau

Usaha perikanan tangkap lainnya terdiri dari gill net dan payang dengan hasil produksi utama juga berupa lemuru. Usaha perikanan tangkap ini menjadi tumpuan dominan (sekitar 80 \%) dari ekonomi nelayan dan masyarakat sekitar (Dinas Kelautan dan Perikanan Kabupaten Banyuwangi, 2010).

Kondisi tersebut tidak akan bertahan lama bila usaha perikanan tangkap tersebut tidak dikelola dengan baik dan tidak ada perimbangan dalam hal finansial. Menurut Hanley dan Spash (1993) dan Wudianto (2001), kelayakan finansial sangat penting untuk memastikan dapat atau tidaknya usaha perikanan tertentu untuk dapat dilanjutkan di masa yang akan datang. Hasil produksi yang bergantung musim di kawasan Selat Bali memberi pengaruh besar bagi usaha perikanan tangkap yang dilakukan nelayan sekitar. Penelitian ini merasa perlu mengkaji kelaykan finansial dari usaha perikanan tangkap tersebut terutama yang banyak dikembangkan dan menopang kehidupan nelayan di kawasan.

\subsection{Tujuan}

Tujuan dari penelitian ini adalah :

a. Menganalisis kebutuhan investasi, biaya operasional, dan penerimaan usaha perikanan tangkap di kawasan Selat Bali.

b. Menganalisis kelayakan finansial usaha perikanan tangkap yang mendukung kesejahteraan nelayan di kawasan Selat Bali.

\section{METODOLOGI}

\subsection{Waktu dan Lokasi Penelitian}

Penelitian ini dilaksanakan selama 9 (sembilan) bulan dimulai dari bulan Desember 2009 sampai dengan Agustus 2010. Lokasi penelitian adalah kawasan Selat Bali di Kabupaten Banyuwangi, Kabupaten Jembrana, dan Kabupaten Buleleng.

\subsection{Jenis Data yang Dikumpulkan}

Data yang dikumpulkan dalam penelitian ini terdiri dari data primer dan data sekunder, mencakup potensi sumberdaya ikan, kapal dan alat dengan produksi paling dominan di lokasi yaitu mencapai 21.552,74 ton per tahun atau sekitar $85 \%$ dari total tangkapan rata-rata per tahun (27.882,73 ton).

tangkap, produksi, pembiayaan usaha, siklus usaha, dan harga jual, keuntungan, dan lainnya.

\subsection{Metode Pengumpulan Data \\ 2.3.1. Metode Pengumpulan Data Primer}

Pengumpulan data primer dapat dilakukan melalui pengamatan langsung di lapang dan pengumpulan data responden. Pengumpulan data responden dilakukan melalui tiga tahap, yaitu kelompok sampling (kelompok stakeholders yang ditanya), identifikasi responden, dan pengumpulan data responden. Responden diambil dari 5 $10 \%$ usaha perikanan tangkap yang aktif beroperasi(Bungin, 2004).

\subsubsection{Metode Pengumpulan Data Sekunder \\ Metode pengumpulan data} sekunder terdiri dari studi literatur, konsultasi pakar, dan kombinasi keduanya.

\subsection{Metode Analisis}

Kelayakan usaha perikanan penting untuk dianalisis sehingga kinerja dan tingkat dukungannya terhadap kesejahteraan nelayan dapat diketahui termasuk pada kondisi produksi yang cenderung turun. Menurut Gaspersz (1992) dan Cahyono (1995), kelayakan usaha dapat diukur dari parameter Net Present Value (NPV), Internal Rate of Return (IRR), Return of Investment (ROI), dan Benefit-Cost Ratio (BCR).

\subsubsection{Net Present Value (NPV)}

NPV merupakan parameter untuk mengetahui selisih antara nilai sekarang dari penerimaan dengan nilai sekarang dari pengeluaran pada tingkat bunga tertentu. Kegiatan perikanan layak dikembangkan bila mempunyai nilai NPV $>0$ (nol). Perhitungan nilai NPV menggunakan rumus :

$$
N P V=\sum_{t=1}^{n} \frac{B t-C t}{(1+i)^{t}}
$$

Dimana $\mathrm{Bt}=$ Penerimaan (benefit) pada tahun ke-t, $\mathrm{Ct}=$ Biaya (cost) pada tahun ke- $\mathrm{t}, \mathrm{i}=$ suku bunga, $\mathrm{t}=1,2,3 . ., \mathrm{n}$, dan $\mathrm{n}$ $=$ umur ekonomis. 


\subsubsection{Internal Rate of Return (IRR)}

IRR merupakan paramater untuk mengetahui suku bunga maksimal untuk sampai kepada NPV $=0$, jadi dalam keadaan batas untung rugi. Kegiatan perikanan layak dikembangkan bila mempunyai nilai IRR > suku bunga bank yang berlaku. Perhitungan nilai IRR menggunakan rumus :

$$
I R R=i_{1}+\left[\frac{\mathrm{NPV}_{1}}{\mathrm{NPV}_{1}-\mathrm{NPV}_{2}}\right]\left(\mathrm{i}_{2}-\mathrm{i}_{1}\right)
$$

Dimana $i_{1}=$ suku bunga yang menyebabkan NPV bernilai positif, $i_{2}=$ suku bunga yang menyebabkan NPV bernilai negatif, $\mathrm{NPV}_{1}=\mathrm{NPV}$ pada suku bunga $i_{1}$, dan $\mathrm{NPV}_{2}=\mathrm{NPV}$ pada suku bunga $i_{2}$.

\subsubsection{Return of Investment (ROI)}

ROI merupakan parameter untuk mengetahui tingkat pengembalian investasi dari benefit (penerimaan) yang diterima pemilik. Kegiatan perikanan layak dikembangkan bila mempunyai nilai ROI > 1 (satu). Perhitungan nilai ROI menggunakan rumus :

$$
R O I=\frac{\sum_{t=1}^{n} B t}{I}
$$

Dimana Bt $=$ Penerimaan $($ benefit $)$ pada tahun ke-t, $\mathrm{I}=$ Investasi, $\mathrm{t}=1,2,3 \ldots \ldots \ldots$, $\mathrm{n}$, dan $\mathrm{n}=$ umur ekonomis.

\subsubsection{Benefit-Cost Ratio (B/C Ratio)}

B/C Ratio merupakan paramater untuk mengetahui tingkat perbandingan antara NPV yang bernilai positif dengan NPV yang bernilai negatif. Kegiatan perikanan layak dikembangkan lanjut bila mempunyai nilai $\mathrm{B} / \mathrm{C}$ Ratio $>1$ (satu). Perhitungan nilai ROI menggunakan rumus :

$$
B / C \text { ratio }=\frac{\sum_{t=0}^{n} \frac{(B t-C t)}{(1-i)^{t}}(B t-C t)>0}{\sum_{t=1}^{n} \frac{(C t-B t)}{(1+i)^{t}}(B t-C t)<0}
$$

Dimana Bt $=$ Penerimaan $($ benefit $)$ pada tahun ke-t, $\mathrm{Ct}=$ Biaya $(\cos t)$ pada tahun ke-t, $\mathrm{i}=$ suku bunga, $\mathrm{t}=1,2,3 \ldots \ldots . . \mathrm{n}$, dan $\mathrm{n}=$ umur ekonomis.

\section{HASIL DAN PEMBAHASAN}

\subsection{Kebutuhan Investasi}

Usaha perikanan yang banyak berkembang di perairan Selat Bali terdiri dari purse seine one boat system (OBS), purse seine two boat system (TBS), gill net dan payang. Keempat usaha perikanan tersebut merupakan merupakan usaha perikanan kategori skala menengah ke atas, sehingga pengoperasiannya perlu didukung oleh biaya investasi yang memadai. Menurut Mamuaya, et. al (2007), bergabung beberapa nelayan dalam suatu kelompok merupakan upaya yang dilakukan nelayan untuk memanfaatkan modal terbatas yang dimiliki sekaligus mempertahankan keberlanjutan usahanya.

Hasil survai lapang menunjukkan bahwa investasi purse seine OBS membutuhkan 1 unit kapal, 1 set alat tangkap jaring purse seine, 1 unit mesin induk sekitar $23 \mathrm{PK}, 1$ set mesin lampu / lampu petromaks, 1 buah echosounder, 1 set roller, 1 buah kompas, 2 buah palka/fiber $800 \mathrm{~kg}, 10$ buah jerigen 35 liter, dan 1 buah sampan/pelampung permanen tempat mengikat satu ujung jaring lainnya. Biaya yang dibutuhkan untuk investasi tersebut sekitar Rp 287,750.000. Kemudian kebutuhan investasi purse seine TBS hampir sama dengan purse TBS, tetapi ada penambahan untuk kapal dan mesin induk. Guna mendukung operasi penangkapan ikan secara maksimal, maka purse seine TBS ini juga dilengkapi dengan roller, palka/fiber isi, dan jerigen. Biaya investasi untuk purse seine TBS sekitar sekitar Rp 476.250.000. Bila dibandingkan purse seine OBS, maka ada peningkatan investasi sekitar $66 \%$. Menurut Dinas Kelautan dan Perikanan Kabupaten Banyuwangi (2010), purse seine one boat system (OBS) menggunakan satu kapal untuk mendukung operasi penangkapan ikan, kalaupun ada alat pendukung hanya berupa perahu kecil atau pelampung permanen yang berfungsi sebagai pengikat ujung jaring. Sementara purse seine two boat system (TBS) menggunakan dua kapal berukuran sama dengan peralatan lengkap, yang mana dalam operasi penangkapan ikan, kedua kapal aktif menarik ujung jaring untuk mengelilingi ikan sasaran secara cepat.

Kebutuhan investasi gill net di Selat Bali mencakup kapal, alat tangkap, alat mesin induk, mesin lampu, kompas, radio $\mathrm{HT}$, fiber/cooler box, jerigen air. 
Biaya investasi untuk gillnet ini mencapai Rp 313.250.000. Kebutuhan investasi gill net termasuk besar. Menurut Wudianto (2001), kapal gill net dibutuhkan besar, karena selain akan membawa alat tangkap (jaring gill net) yang berukuran besar, juga harus cukup aman untuk perjalanan jauh dalam penangkapan ikan dan dengan membawa ABK yang banyak untuk setiap kali operasi penangkapan.

Kebutuhan investasi payang di Selat Bali mencakup kapal payang, jaring payang, mesin induk, mesin lampu, kompas, radio HT, palka/fiber isi dan jerigen air. Biaya investasi untuk payang tersebut mencapai Rp 261.150.000, dimana alat tangkapnya (jaring payang) umumnya didatangkan dari luar seperti Tuban dan Tegal. Investasi mesin induk payang lebih rendah dari mesin induk gill net, yaitu 23 PK dengan biaya investasi sekitar Rp 30.000.000. Menurut Tinungki (2005) dan Dinas PKL Kabupaten Jembrana (2009), penggunaan mesin ukuran sedang ini lebih karena jaungkauan operasinya relatif lebih dekat dan hampir sama dengan jangkauan operasi purse seine TBS dan OBS, yaitu sekitar perairan yang menjadi kewenangan tiap kabupaten di Selat Bali.

\subsection{Kebutuhan Operasional Usaha Perikanan}

Secara umum, baik dalam operasi purse seine OBS, purse seine TBS, gill net maupun payang biasanya menggunakan sistem operasi one day fishing, yaitu satu trip dilakukan dalam satu hari. Menurut DKP (2004), sistem operasi penangkapan one day fishing sudah umum dilakukan nelayan purse seine, gill net, dan payang di Indonesia, dan hal ini diikuti secara turun temurun.

Menurut Ruddle et. al (1992) dan Kompas (2003), tahap operasi merupakan tahapan yang sangat penting dalam pengembangan suatu usaha ekonomi termasuk di bidang perikanan dan umumnya bergantung pada musim. Pada musim paceklik, operasi penangkapan ikan menggunakan purse seine, gill net, dan payang dapat berturut-turut dapat mencapai 20 trip, 20 trip, dan 15 trip. Sementara pada musim biasa dan musim puncak, operasi penangkapan ikan menggunakan purse seine, gill net, dan payang dapat berturtut-turut dapat mencapai 100 trip dan 100 trip, 90 trip dan 90 trip, serta 85 trip dan 90 trip. Setiap tahunnya, musim paceklik biasanya terjadi pada bulan AgustusSeptember, musim sedang biasanya terjadi pada Februari-Juli, dan musim puncak terjadi pada bulan OktoberPebruari. Tabel 1 menyajikan kebutuhan operasional purse seine OBS, purse seine TBS, gill net, dan payang setiap tripnya di kawasan Selat Bali.

Berdasarkan Tabel 1, penggunaan bensin dan minyak tanah dalam operasi payang lebih sedikit daripada purse seine dan gill net yaitu masing-masing 1 liter dan 2 liter setiap trip operasi. Bensin dan minyak tanah tersebut hanya digunakan bila nelayan payang pulang agak larut malam, misalnya karena berangkatnya di siang hari dan lainnya. Menurut Cochrane (2002), pengaturan operasi merupakan cara yang paling tepat untuk mendapatkan keuntungan ekonomi maksimal dari suatu usaha perikanan. Penggunaan solar juga lebih sedikit pada payang, yaitu sekitar 150 liter per trip (Rp 675.000 per trip) atau sekitar 31.500 liter per tahun (Rp 148.500.000 per tahun). Hal ini karena karena lama operasi penangkapan ikan menggunakan payang sedikit lebih rendah, yaitu hanya sekitar 6-8 jam.

Penggunaan solar pada purse seine TBS lebih banyak daripada purse seine OBS, karena mesin kedua kapal yang digunakan dalam operasi purse seine TBS tetap dihidupkan selama operasi penangkapan berlangsung di fishing ground. Hal yang sama juga terjadi pada pengunaan es, air tawar, dan perbekalan karena hasil tangkapan purse seine TBS yang perlu didinginkan banyak dan juga jumlah ABK yang ikut serta juga dua kali lebih banyak, yaitu bisa mencapai 34 orang. Kebutuhan ransum pada operasi gill net lebih sedikit dibandingkan purse seine dan payang. Menurut Tungki (2005), hal ini bisa jadi karena intensitas operasi (setting) dalam operasi gill net tidak begitu banyak (umumnya 2 kali setting per trip), sehingga energi yang dikeluarkan nelayan relatif sedikit meskipun waktu operasinya sedikit lebih lama.

\subsection{Penerimaan Usaha Perikanan}

Penerimaan yang diperoleh nelayan dari operasi penangkapan ikan menggunakan purse seine one boat system, purse seine two boat system, gill 
net, dan payang dapat dihitung dari hasil tangkapan yang diperoleh setiap trip operasi yang dilakukan. Jenis ikan yang ditangkap umumnya terdiri dari ikan lemuru, layang, tongkol, dan lainnya. Gambar 1 menyajikan perbandingan jumlah hasil tangkapan, purse seine one boat system (OBS), purse seine two boat system (TBS), gill net, dan payang setiap tripnya pada musim puncak, sedang, dan paceklik di Selat Bali.

Berdasarkan Gambar 1, hasil tangkapan purse seine TBS paling tinggi di setiap musim dibandingkan usaha perikanan lainnya, yaitu pada musim puncak, sedang, dan paceklik berturutturut adalah $3.127 \mathrm{~kg}$ per trip, $2.310 \mathrm{~kg}$ per trip, dan $1.417 \mathrm{~kg}$ per trip. Hal ini karena alat tangkap purse seine TBS ini sangat aktif, menggunakan dua kapal yang keduanya dioperasikan sekaligus dalam operasi penangkapan ikan. Namun demikian, keempat usaha perikanan tersebut mempunyai hasil tangkapan yang cukup fluktuatif di setiap musimnya.

Menurut Cochrane (2002), produksi yang fluktuatif menjadi penyebab utama harga jual ikan berbeda-beda di setiap musim. Pada musim paceklik, harga jual rata-rata hasil tangkapan purse seine OBS, purse seine TBS, gill net, dan payang sekitar Rp 4.800 per kg, sedangkan pada musim sedang karena jumlah ikan lebih banyak turun menjadi Rp 4.000 per kg, dan pada musim puncak turun lagi menjadi sekitar $\mathrm{Rp}$ 3.000 per $\mathrm{kg}$. Hal ini dapat dipahami,

Tabel 1. Kebutuhan operasional purse seine OBS, purse seine TBS, gill net, dan payang di kawasan Selat Bali

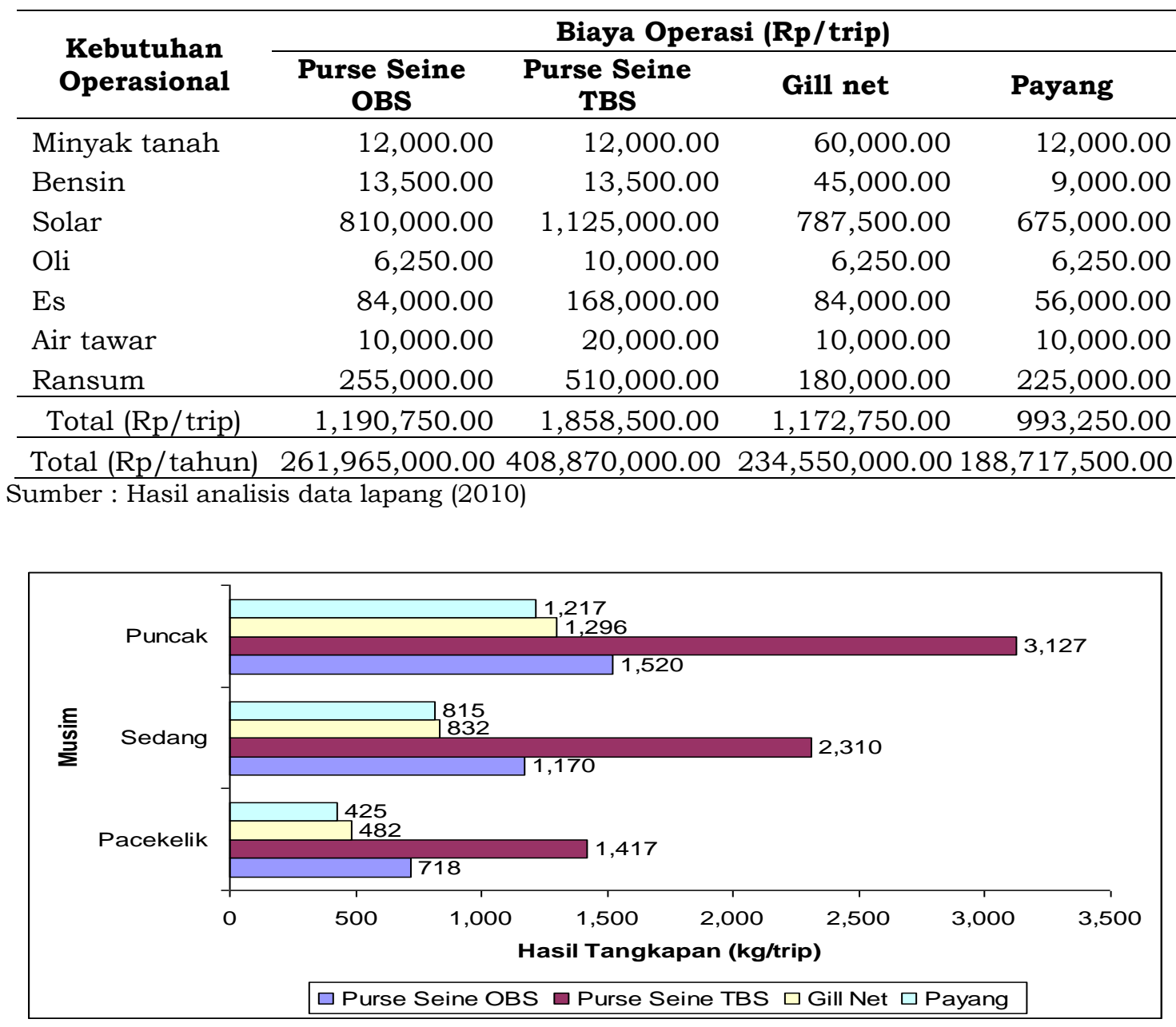

Gambar 1. Hasil tangkapan per trip purse seine OBS, purse seine TBS, gill net, dan payang berdasarkan musim 
karena semakin banyak ikan, maka alternatif bagi pembeli dan distributor banyak, sedangkan nelayan harus segera menjual hasil tangkapannya biar tidak rusak. Namun demikian, secara umum harga jual tersebut termasuk rendah yang disebabkan oleh hasil tangkapan nelayan umumnya berupa ikan lemuru $(79,97 \%)$, dimana harga jual lemuru tersebut hanya berkisar Rp $2.000-\mathrm{Rp}$ 3.500 per $\mathrm{kg}$.

Untuk menghindari fluktuasi harga yang terlalu tinggi dan cenderung merugikan nelayan, maka Pemerintah Daerah di tiga kabupaten terkait (Banyuwangi, Jembrana, dan Buleleng) perlu membuat dan mengatur mekanisme perdagangan produk hasil perikanan, sehingga harga jual tidak di monopoli oleh pembeli/distributor besar. Pengaturan dalam SKB No. 238 Tahun 1992//674 tahun 1992 terkait pengendalian pemasaran dan menghimbau kerjasama tempat pelelangan ikan (TPI) dan KUD Mina di setiap lokasi merupakan upaya yang tepat untuk mengendalian harga juga ikan di kawasan Selat Bali sehingga tetap stabil, kompetitif dan menguntungkan nelayan. Tabel 2 menyajikan kondisi penerimaan dari operasi purse seine TBS, purse seine OBS, gill net dan payang setiap musimnya di kawasan Selat Bali.

Berdasarkan Tabel 2, jumlah penerimaan yang diperoleh setiap tahunnya dari operasi purse seine OBS sekitar Rp 992.929.000, purse seine OBS sekitar Rp 1.998.132.00, gill net sekitar $\mathrm{Rp}$ 673.292.000 dan payang sekitar $\mathrm{Rp}$ 636.290.000. Menurut data tersebut, purse seine merupakan usaha perikanan dengan penerimaan paling tinggi, dibandingkan tiga usaha perikanan lainnya di Selat Bali. Hal ini lebih didukung oleh mekanisme operasi yang memanfaatkan dua kapal secara aktif sehingga produktivitas penangkapan lebih tinggi. Secara umum, usaha purse seine baik TBS maupun OBS mempunyai penerimaan yang lebih tinggi. Menurut Mamuaya et al (2007), jumlah penerimaan menjadi faktor penentu utama bkeberlanjutan usaha perikanan di suatu kawasan, sedangkan menurut Dinas Kelautan dan Perikanan Propinsi Jawa Timur (2009), penerimaan tinggi menjadi penyebab purse seine lebih banyak dikembangkan di kawasan dibandingkan usaha perikanan lainnya.

\subsection{Kelayakan Usaha Berdasarkan Parameter Finansial \\ 3.4.1.Kelayakan Usaha Berdasarkan Net Present Value (NPV)}

Parameter Net Present Value (NPV) digunakan untuk mengetahui kelayakan usaha perikanan purse seine OBS, purse seine TBS, gill net dan payang berdasarkan selisih antara nilai sekarang (present) dari penerimaan dengan nilai sekarang dari pengeluaran pada tingkat bunga tertentu yang berlaku yang terjadi selama operasi keempat usaha perikanan tersebut. Suku buka yang berlaku pada periode tersebut sekitar 6,25 \% (Bank Indonesia, 2010). Hasil analisis kelayakan usaha perikanan purse seine one boat system (OBS), purse seine two boat system (TBS), gill net dan payang di Selat Bali berdasarkan Net Present Value (NPV) disajikan pada Tabel 3.

Tabel 2. Kondisi penerimaan dari operasi purse seine TBS, purse seine OBS, gill net dan payang

\begin{tabular}{ccccc}
\hline \multirow{2}{*}{ Musim } & \multicolumn{4}{c}{ Penerimaan (Rp) } \\
\cline { 2 - 5 } & $\begin{array}{c}\text { Purse Seine } \\
\text { OBS }\end{array}$ & Purse Seine TBS & Gill Net & Payang \\
\hline Puncak & $456,000,000$ & $938,100,000$ & $349,920,000$ & $328,590,000$ \\
Sedang & $468,000,000$ & $924,000,000$ & $277,100,000$ & $277,100,000$ \\
Paceklik & $68,928,000$ & $136,032,000$ & $46,272,000$ & $30,600,000$ \\
\hline Total $(\mathrm{Rp})$ & $992,928,000$ & $1,998,132,000$ & $673,292,000$ & $636,290,000$ \\
\hline
\end{tabular}

Sumber : Hasil analisis data lapang (2010) 
Tabel 3. Kelayakan usaha perikanan berdasarkan Net Present Value (NPV)

\begin{tabular}{lcrc}
\hline \multicolumn{1}{c}{ Usaha Perikanan } & Standar NPV & \multicolumn{1}{c}{ Nilai NPV } & Keterangan \\
\hline Purse Seine OBS & $>0$ & $1,755,080,046.41$ & Layak \\
Purse Seine TBS & & $4,070,067,018.54$ & Layak \\
Gill Net & & $918,548,267.25$ & Layak \\
Payang & & $982,670,737.88$ & Layak \\
\hline
\end{tabular}

Sumber : Hasil analisis data lapang (2010)

Berdasarkan Tabel 3 tersebut, nilai NPV purse seine TBS paling tinggi $(\mathrm{Rp}$ 4.070.067.018,54). Hal ini menunjukkan bahwa purse seine dapat memberikan keuntungan bersih sebesar $\mathrm{Rp}$ 4.070.067.018,54 selama masa operasinya jika diukur dari nilai sekarang yaitu setelah mempertimbangkan kondisi bunga bank sekitar 6,25\%. Hasil survai lapang menunjukkan bahwa usaha perikanan purse seine, gillnet, dan payang dapat dioperasikan secara layak /normal selama 8 tahun. Keuntungan bersih ini lebih disebabkan oleh penerimaan bersih purse seine TBS yang tinggi, yaitu mencapai Rp 1.998.132.000 (Tabel 2), sementara biaya operasional relatif standar $(\mathrm{Rp} 1.858 .500$ per trip atau Rp 408.870.000 per tahun). Terkait dengan ini, maka dari segi NPV, usaha perikanan purse seine TBS mempunyai prospek yang sangat baik untuk pengembangannya termasuk sebagai usaha perikanan unggulan di kawasan Selat Bali. Menurut Hanley dan Spash (993), nilai NPV tersebut cerminan keuntungan bersih yang didapat pelaku usaha pada kondisi terakhir saat keuntungan dihitung.

Terhadap kondisi tersebut, maka purse seine OBS, purse seine TBS, gill net dan payang di Selat Bali tidak perlu diragukan lagi sumbangan keuntungannya, meskipun keempatnya menggunakan ABK yang cukup banyak dalam setiap trip operasi penangkapan yang dilakukannya. Hal ini tentu sangat baik, mengingat usaha perikanan tersebut telah dikuasai nelayan, dan nelayan Selat Bali tinggal melanjutkannya (Wudianto, 2001).

\subsubsection{Kelayakan Usaha Berdasarkan Internal Rate Return (IRR)}

Paramater Internal Rate Return (IRR) merupakan parameter untuk mengetahui batas untung rugi suatu usaha perikanan, yang ditunjukkan oleh suku bunga maksimal yang menyebabkan NPV $=0$. Dari empat usaha perikanan tersebut, purse seine TBS mempunyai nilai IRR paling tinggi $(140,15 \%)$ (Tabel 4). Nilai IRR ini memberi pengertian bahwa menginvestasikan uang pada usaha perikanan purse seine TBS di Selat Bali akan mendatangkan keuntungan sekitar 140,15 \% per tahunnya. Hal ini bisa jadi merupakan penyebab nelayan atau pengusaha perikanan yang punya uang lebih selalu ingin mengembangkan usaha perikanan purse seine TBS tersebut meskipun jumlah purse seine yang ada sudah maksimum sesuai kuota (Dinas Kelautan dan perikanan Jawa Timur, 2009). Menurut SKB No 7 Tahun 1985//4 Tahun 1985 maupun No. 238 Tahun 1992//674 Tahun 1992, kuota purse seine baik TBS maupun OBS yang diijinkan diperairan Selat Bali adalah maksimum 273 unit dengan rincian Propinsi JawaTimur 190 unit dan Propinsi Bali 83 unit.

Tabel 4. Kelayakan usaha perikanan berdasarkan Internal Rate Return (IRR)

\begin{tabular}{lccc}
\hline \multicolumn{1}{c}{ Usaha Perikanan } & Standar IRR & Nilai IRR & Keterangan \\
\hline Purse Seine OBS & $>6.25$ & $102.55 \%$ & Layak \\
Purse Seine TBS & & $140.15 \%$ & Layak \\
Gill Net & & $53.08 \%$ & Layak \\
Payang & & $66.25 \%$ & Layak \\
\hline
\end{tabular}

Sumber : Hasil analisis data lapang (2010) 
Tabel 5. Kelayakan usaha perikanan berdasarkan Return of Investment (ROI)

\begin{tabular}{lccc}
\hline \multicolumn{1}{c}{ Usaha Perikanan } & Standar ROI & Nilai ROI & Keterangan \\
\hline Purse Seine OBS & $>1$ & 21.22 & Layak \\
Purse Seine TBS & & 25.80 & Layak \\
Gill Net & & 13.66 & Layak \\
Payang & & 14.98 & Layak \\
\hline
\end{tabular}

Sumber : Hasil analisis data lapang (2010)

Nilai IRR untuk purse seine OBS, gill net dan payang juga termasuk bagus, karena suku bunga bank yang berlaku hanya 6,25\% (bunga deposito). Oleh karena semua parameter finansial penting dari analisis kelayakan usaha dapat dipenuhi dengan baik oleh usaha perikanan purse seine TBS, purse seine OBS, gill net maupun payang, maka keempat usaha perikanan ini sangat layak tanpa syarat finansial apapun dilanjutkan termasuk menjadikannya sebagai usaha perikanan unggulan dan penopang kesejahteraan nelayan di kawasan Selat Bali. Mekanisme operasi yang dilakukan selama ini, termasuk waktu operasi, lama operasi per trip, dan lainnya dapat terus dilanjutkan karena sudah termasuk efektif. Untuk daerah penangkapan ikan perlu lebih selektif dalam memilihnya, dimana kegiatan penangkapan perlu dihindari pada kawasan yang banyak terumbu karangnya dan kawasan yang banyak kegiatan budidaya laut sehingga tidak ada konflik pengelolaan. Menurut White et. al (1994), terumbu karang merupakan habitat berbagai jenis ikan yang membawa manfaat ekonomi bagi masyarakat luas, dan oleh karenanya masyarakat diberi penyadaran dan dilbatkan dalam berbagai kegiatan konservasi biota.

\subsubsection{Kelayakan Usaha Berdasarkan Return of Investment (ROI)}

Hasil analisis kelayakan terhadap keempat usaha perikanan tersebut berdasarkan parameter Return of Investment (ROI) disajikan pada Tabel 5. Berdasarkan Tabel 5, tersebut purse seine TBS, purse seine OBS, gill net, dan payang layak dikembangkan di kawasan Selat Bali karena mempunyai nilai ROI > 1.Nilai ROI yang tinggi ini terjadi karena keempat usaha perikanan tersebut mempunyai penerimaan yang sangat baik (Tabel 2), sementara biaya investasinya relatif standar dan alat bantu berteknologi tinggi. Misalnya pada usaha perikanan purse seine OBS dapat memberi penerimaan sekitar $\mathrm{Rp}$ 992.928.000 per tahun atau sekitar $\mathrm{Rp}$ 7.943.424.000 selama masa operasinya, sementara biaya investasi yang dibutuhkan untuk pengadaan purse seine OBS tersebut sekitar Rp 287.750.000. Menurut Setiawan et. al (2007), termasuk penciri penting kelayakan investasi karena menunjukkan kelipatan jumlah investasi yang bisa dikembalikan bila usaha perikanan tersebut dilakukan di Selat Bali.

Untuk purse seine TBS, bila membutuhkan biaya investasi untuk pengadaan kapal, alat tangkap purse seine, dan alat pendukung penangkapan sekitar Rp 476.250.000, maka setelah 8 tahun pengoperasiannya akan dapat mengembalikan biaya investasi tersebut sebesar 21,22 kalinya. Hal yang sama juga untuk gill net dan payang, yaitu dapat membayar masing-masing sebesar 13,66 dan 14,98 dari biaya investasi yang dikeluarkannya pada saat awal usaha perikanan tersebut dimulai. Melihat tingkat pengembalian investasi ini, maka baik purse seine TBS, purse seine OBS, gill net, maupun payang dapat menjadi alternatif untuk pengembangan usaha perikanan pada kondisi anggaran terbatas, termasuk dalam mendukung program pemerintah yang memanfaatkan sistem pendanaan secara bergulir (Dinas PKL Kabupaten Jembrana, 2009).

\subsubsection{Kelayakan Usaha Berdasarkan Benefit-Cost Ratio (B/C Ratio)}

Dalam penelitian ini, parameter Benefit-Cost Ratio (B/C Ratio) digunakan untuk kelayakan usaha perikanan dengan melihat perimbangan antara penerimaan usaha perikanan tersebut dengan pembiayaan yang dikeluarkan untuk mengoperasikan usaha perikanan tersebut. Berdasarkan Tabel 6, usaha perikanan purse seine OBS, purse seine TBS, gill net dan payang layak dilanjutkan di Selat Bali karena 
mempunyai nilai B/C Ratio yang lebih dari 1 (satu).

Untuk purse seine two boat system (TBS) misalnya, setiap 1 (satu) satuan biaya yang dikeluarkan untuk menjalankan usaha purse seine TBS tersebut di Selat, maka akan mendatangkan penerimaan bersih sekitar 1,50 satuan. Hal yang sama juga untuk gill net dan payang, dimana setiap 1 satuan biaya yang dikeluarkan, maka akan mendatangkan penerimaan bersih masing-masing 1,27 satuan dan 1,34 satuan. Secara sepintas, jumlah penerimaan bersih berdasarkan analisis B/C Ratio ini tidak terlalu besar. Hal ini karena pembandingnya merupakan akumulasi biaya yang dikeluarkan selama menjalankan usaha perikanan tersebut (8 tahun). Setiap nelayan berangkat melaut, maka sebagian dari penerimaannya, digunakan kembali menjadi biaya operasional dan diawal operasi nelayan juga sudah mengeluarkan biaya untuk investasi. Bila semua biaya-biaya tersebut diperhitungkan, maka tentu sangat banyak, sehingga sangat wajar bila rasio penerimaan dikatakan baik dengan hanya lebih beberapa satuan dari akumulasi biaya tersebut (Hanley dan Spash, 1993).

Terlepas dari ini semua, purse seine OBS, purse seine TBS, gill net dan payang layak untuk dikembangkan lanjut di kawasan Selat Bali, karena semua parameter finansial yang dipersyaratkan dapat dipenuhi dengan baik. Bila keempat usaha perikanan tersebut diperbandingkan, maka purse seine two boat system (TBS) paling layak. Purse seine two boat system (TBS) mempunyai nilai paling baik untuk parameter NPV, IRR, ROI, maupun B/C Ratio. Terkait dengan ini, maka pengembangan usaha perikanan ini perlu dipertahankan, meskipun jumlahnya harus dibatasi sesuai dengan alokasi purse seine yang diatur dalam SKB No. 238 Tahun 1992//674 tahun 1992. Hal ini karena purse seine two boat system (TBS) lebih menyakinkan dalam meningkatkan kesejahteraan nelayan dan perekonomian kawasan yang ditunjukkan. Nilai NPV, IRR, ROI, maupun B/C Ratio menjadi indikasi nyata dari hal ini.

Tabel 6. Kelayakan usaha perikanan berdasarkan Benefit-Cost Ratio (B/C Ratio)

\begin{tabular}{lccc}
\hline \multicolumn{1}{c}{ Usaha Perikanan } & Standar R/C & Nilai R/C & Keterangan \\
\hline Purse Seine OBS & $>1$ & 1.40 & Layak \\
Purse Seine TBS & & 1.50 & Layak \\
Gill Net & & 1.27 & Layak \\
Payang & & 1.34 & Layak \\
\hline
\end{tabular}

Sumber : Hasil analisis data lapang (2010)

\section{KESIMPULAN DAN SARAN}

\subsection{Kesimpulan}

Usaha perikanan tangkap yang dominan dan berkontribusi besar bagi kesejahteraan nelayan di kawasan Selat Bali ada empat, yaitu purse seine one boat system (OBS), purse seine two boat system (TBS), gill net dan payang. Kebutuhan investasi purse seine OBS, purse seine TBS, gill net dan payang berturut-turut adalah Rp 287,750.000, Rp 476.250.000, Rp 313.250.000, dan Rp 261.150.000. Kebutuhan operasional tahunan purse seine OBS, purse seine TBS, gill net dan payang berturut-turut adalah $\mathrm{Rp}$ 261.965.000, Rp 408.870.000, Rp 234.550.000, dan Rp 188.717.500. Sedangkan penerimaan tahunan purse seine OBS, purse seine TBS, gill net dan payang berturut-turut adalahRp
992.928.000, Rp 1.998.132.000, Rp 673.292.000, dan Rp 636.290.000.

Keempat usaha perikanan tersebut tersebut termasuk 'sangat layak' untuk dikembangkan lanjut guna mendukung kesejahteraan nelayan di kawasan Selat Bali, karena mempunyai nilai NPV, IRR, ROI, maupun B/C Ratio yang lebih baik dari yang dipersyaratkan. Purse seine OBS mempunyai NPV sekitar Rp 1.755.080.046,41, IRR sekitar 102,55 \%, ROI sekitar 21,22, dan $\mathrm{R} / \mathrm{C}$ ratio sekitar 1,40. Purse seine TBS mempunyai NPV sekitar Rp 4.070.067.018,54, IRR sekitar 140,15\%, ROI sekitar 25,80, dan R/C ratio sekitar 1,50 . Gill net mempunyai NPV sekitar Rp 918.548.267,25, IRR sekitar 53,08 \%, ROI sekitar 13,66, dan $\mathrm{R} / \mathrm{C}$ ratio sekitar 1,27 , dan payang mempunyai NPV sekitar Rp 
982.670.737,88, IRR sekitar 66,25 \%, ROI sekitar 14,98, dan $\mathrm{R} / \mathrm{C}$ ratio sekitar 1,34 .

\subsection{Saran}

Usaha perikanan purse seine one OBS, purse seine TBS, gill net dan payang di perairan Selat Bali perlu diatur dengan baik, sehingga tidak menimbulkan efek destruktif terhadap lingkungan perairan, mengingat usaha perikanan tersebut telah menjadi andalan untuk meningkatkan kesejahteraan nelayan di kawasan Selat Bali. Pelaksanaan SKB No. 238 Tahun 1992//674 tahun 1992 perlu dievaluasi oleh PEMDA terkait melalui pertemuan yang dijadwalkan secara rutin.

\section{DAFTAR PUSTAKA}

Bungin B. 2004. Metode Penelitian Kuantitatif. Raja Grafindo Persada. Jakarta.

Cahyono B. T. 1995, Manajemen Strategi Pemasaran. Sekolah Tinggi Ilmu Ekonomi IPWI Program Magister Manajemen. Badan Penerbit IPWI Jakarta.

Cochrane, K. L. 2002. A Fishery Manager's Guidebook. Management Measures and Their Application. Senior Fishery Resources Officer. Fishery Resources Division, FAO Fisheries Department. Rome. $231 \mathrm{pp}$.

Departemen Kelautan dan Perikanan [DKP]. 2008. Studi Pengembangan Kebijakan Perikanan Berbasis Kawasan. Progrem Kerjasama Ditjen KP3K-DKP. Jakarta.

Departemen Kelautan dan Perikanan (DKP). 2004. Statistik Perikanan Tangkap Indonesia, 2002. DKP, Jakarta. 101 hal.

Dinas Kelautan dan Perikanan Propinsi Jawa Timur. 2009. Prospek Pengembangan Perikanan di Kawasan Selat Bali Berbasis Potensi Lokal. Dinas Kelautan dan Perikanan Propinsi Jawa Timur. Surabaya.

Dinas Kelautan dan Perikanan Kabupaten Banyuwangi. 2010. Pengelolaan Potensi Perikanan Selat Bali, Tantangan dan Permasalahannya. Dinas Kelautan dan Perikanan Kabupaten Banyuwangi. Banyuwangi.
Dinas Pertanian, Kehutanan, dan Kelautan (PKL) Kabupaten Jembrana. 2009. Dinamika Produksi Perikanan Selat Bali dan Peluang Pengembangannya. Laporan Kegiatan. Jembrana.

Gaspersz V. 1992. Analisis Sistem Terapan Berdasarkan Pendekatan Teknik Industri. Tarsito Press. Bandung.

Hanley ND. and Spash C 1993. CostBenefic Analysis and the Environment. Edward Elgar, Cheltenham, UK.

Kompas. 2003. Mampukah Indonesia Jadi Pemain Utama di Pasar Dunia?, http:/ / www.kapet.org/articles / arti cledetail.asp?id=22.

Mamuaya GE., Haluan J, Wisudo SH, dan Astika IW. 2007. Status Keberlanjutan Perikanan Tangkap di Daerah Kota Pantai : Penelaahan Kasus di Kota Manado. Buletin PSP Vol. XVI. 1 : 146-160.

Ruddle, K., E. Hviding, and R. E. Johannes. 1992. Marine Resource Management In The Context Of Customary Tenure. Marine Resource Economics, (7), pp. 249273.

Setiawan I, Monintja DR., Nikijuluw VPH, dan Sondita MFA. 2007. Analisis Ketergantungan Daerah Perikanan sebagai Dasar Pelaksanaan Program Pemberdayaan Nelayan : Studi Kasus di Kabupaten Cirebon dan Indramayu. Buletin PSP Vol. XVI. 2 : 188-200.

Tinungki G.M. 2005. Evaluasi Model Produksi Surplus Dalam Menduga Hasil Tangkapan Maksimum Lestari Untuk Menunjang Kebijakan Pengelolaan Perikanan Lemuru di Selat Bali, Sekolah Pasca Sarjana, IPB.

White, A.L. L. Z. Hale, Y. Renard, and L. Cortesi. 1994. Collaborative and Community Based Management of Coral Reef: lessons from experience. Kumarian Press, Inc., West Hartford, Connecticut.

Wudianto. 2001, Analisis Sebaran dan Kelimpahan Ikan Lemuru (Sardinella lemuru Bleeker 1853) di Perairan Selat Bali: Kaitannya dengan Optimasi Penangkapan, Program Pasca Sarjana, IPB. 